
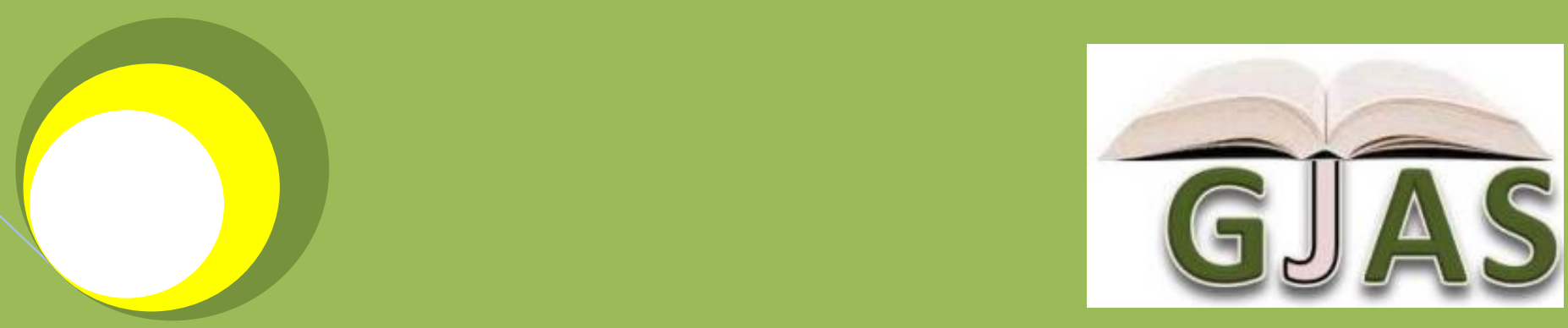

Greener lournal of Agriculltural Sciences

$$
\text { ISSN: 2276-7770 ICV: } 6.15
$$

\title{
Food and Feeding Ecology of Common Bulbul (Pycnonotus barbatus) in Leventis Foundation Agricultural School llesa South Western Nigeria
}

By

Okosodo E.F. Orimaye J.O. Obasogie F.O.

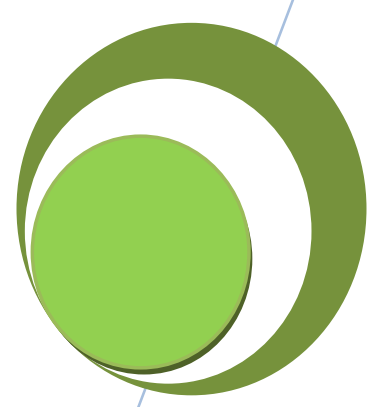




\title{
Food and Feeding Ecology of Common Bulbul (Pycnonotus barbatus) in Leventis Foundation Agricultural School Ilesa South Western Nigeria
}

\author{
Okosodo E.F. ${ }^{1 \star}$, Orimaye J.O. ${ }^{2}$ and Obasogie F.O. ${ }^{3}$
}

\author{
${ }^{1}$ Department of Ecotourism and Wildlife Management, Federal University of Technology, PMB 1054 Akure, Ondo \\ State, Nigeria. \\ ${ }^{2}$ Forestry, Wildlife and Fisheries Management Dept; Ekiti State University, Ado-Ekiti. \\ ${ }^{3}$ College of Agriculture, Iguoriakhi, Benin city, Edo State, Nigeria.
}

Corresponding Author's E-mail: okosodo04@ yahoo.co. uk

\begin{abstract}
This study examined the food and feeding ecology of the Common Bulbul (Pycnonotus babatus) in Leventis Foundation Nigeria Agricultural Training School, South Western Nigeria. Direct field observation method was used to collect data for 12 months on the food and feeding ecology of these bird species. The study area was divided into three compartments according to land use types (secondary forest, Farmland and Developed Area). The result showed that the Common bulbul consumed variety of plants and insects, Ficus exaparataa provided the highest food source (fruits and seeds) and they also consumed the leaves and flowers of the following plants Moringa oleifera, Delonis regia and Boerhavia diffusa. Tree species provided the highest food source of $66.7 \%$ and insects $33.7 \%$. The result revealed that the Common Bulbul Utilized the three Compartments within the study area and that secondary forest provided highest food materials of $69.68 \%$, Farmland $21.12 \%$ and Developed area $9.2 \%$
\end{abstract}

Key Words: Food, Ecology, Habits, conservation.

\section{INTRODUCTION}

Common Bulbul has an extremely large range in Nigeria, the bird species occur in different numbers of habitats within the country's vegetation that range from the mangrove along the coast in the south to the Sahel in the north (Borrow, and Demey, 2012). This bird does not approach the thresholds for Vulnerable under the range size criterion (Extent of Occurrence $<20,000 \mathrm{~km} 2$ combined with a declining or fluctuating range size, habitat extent/quality, or population size and a small number of locations or severe fragmentation (del Hoyo et al. 2005). It has been widely demonstrated that food abundance and distribution are the primary determinants of foraging behaviour in bird species (Lan, et al, 2013). Optimal foraging behavior, however, may encompass other conflicting activities such as anti- predator behaviors that lead animals to trade food intake rate against other activities. Decision-making based on trade-offs may be influenced by the internal state of the animal (Krebs and Kacelnik 1991). Closely related birds nearly always show differences in the frequency of use of foraging maneuvers (Liu, 1992). Feeding is an essential activity in bird's life which is indispensable for their survival, but the demands of food acquisition impose significant challenges to both the physiology and behavior of birds. (Chen and Hsieh, 2002). The study of feeding ecology is thus imperative for understanding the species ecological adaptation to the environment and is also a crucial factor to be considered while examining their economic status. The Common Bulbul is very widely distributed throughout the Nigeria. These small birds form a complex and stable society and are very social even during breeding (Morrison et al, 1990). Studies regarding feeding of common Bulbul have not been undertaken in this part of the country hence, this study will provide baseline information that will help in the conservation of this bird species. 


\section{MATERIALS AND METHODS}

\section{Study Area}

Leventis Foundation Agricultural Training School, llesa is located on the former premises of the former Farm Institute Ilesa in Tropical rain forest zone with central coordinates of $078.055^{\prime} 032 \mathrm{~N}$ and $068.33 .55 \mathrm{E}$. It is about $45 \mathrm{~km}$ from Oshogbo the capital of Osun of State, Southwest Nigeria. Two rivers run across the area creating a valley of watershed and the land mass is 360 ha including the administrative blocks. The area is $360-400 \mathrm{~m}$ above the sea level which is characterized by lateritic soils, sloping topography and hydromorphic valley bottom soils typical for most of the southwestern part of Nigeria. Annual rainfall varies between 1600 and $2000 \mathrm{ml}$, mean annual temperature is $30{ }^{\circ} \mathrm{C}$ and the relative humidity is not below $40 \%$ during dry season and $100 \%$ during the wet season (Mengistu, and Salami, 2007). The study site experiences a bimodal annual rainfall pattern, between April and July and from September to October, separated by dry season. Vegetation is predominantly rainforest, including wetlands along the rivers and Panicum maximum dominated open land. Among the common trees are Celtis zenkerii, Triplochiton scleroxylon, Antiaris africana, Pycnanthus angolensis and Alstonia boonei (Keay 1989).

\section{Method}

The study area was divided into three compartments according to land use types, Secondary Forest, Farmland and Developed areas, and observations of the diet and feeding ecology was carried in these compartments. Present study on feeding ecology of Common Bulbul (Pycnonotus barbatus) was made on 22 groups ranging in size from 2 to 8 individuals. The data was collected during a continuous period of 12 months from January, to December, 2014. Data was collected from the field by direct observation method and by using binocular (Bushnell 7 X 50) whenever found necessary (Anthal and Sadi, 2013). The observations were made early in the morning or late in the evening when common Bulbul are actively feeding with least disturbance to the birds. Individual groups of these birds were followed for periods varying from 2 to 6 hours. While following groups it was usually possible to keep some birds in view at all times, but rarely possible to see all members of the group together. During each scan, observations on the foraging habitat, type of feeding method employed, feeding session, size of the flock, type of diet and association with other bird species were recorded. Seasonal changes in the feeding habits of the Common Bulbul were studied too.

\section{RESULTS}

From this study the result showed that the Common Bulbul feed on variety of plants and insect species. Plant provided highest source of food source (66.7\%) and insects (33.7\%) Ficus exaparataa constituted the highest $(8.7 \%)$ fruits consumed by Common Bulbul. The result revealed that these birds consumed flowers and leaves of Moringa oleifera, Delonis regia and Boerhavia diffusa. It was observed that the Common Bulbul change food with season, depending on the available preferred food in the season. From the result obtained it showed that Common Bulbul utilized the three compartments in the study area. The secondary forest provided the highest food source of $69.8 \%$, followed by Farmland 21.12\% and Developed area 9.2\% 
Table 1: Plant Species Consumed by Common Bulbul in the Study Area

\begin{tabular}{|c|c|c|c|c|}
\hline Common Name & Scientific Name & Family & Parts Eaten & $\begin{array}{l}\text { Observations } \\
(\%)\end{array}$ \\
\hline Fig Tree & Ficus Exaparata & Moraceae & Fruits & 8.7 \\
\hline Flame of the Forest & Delonis regia & Leguminosae & Flowers & 2 \\
\hline Fig Tree & Ficus Pilota & Moraceae & Fruits & 6.5 \\
\hline Hog Plum & Spondia Mombin & Anacardiaceae & Fruits & 2.4 \\
\hline Neam & Azadirachita indica & $\underline{\text { Meliaceae }}$ & Seeds & 3.4 \\
\hline Banana & Musa spp & Musaceae & Fruits & 3.1 \\
\hline African Breadfruit & Treculia Africana & Moraceae & Fruits & 1.6 \\
\hline Vervet Amond Tree & Dallium guineese & Leguminosae & Fruits & 2 \\
\hline Rice & Oryza glaberrima & $\underline{\text { Poaceae }}$ & Seeds & 2.2 \\
\hline Plantain & Musa paradisiacal & Musaceae & Fruits & 1.9 \\
\hline Vitex donania & Vitex donania & Verbenacea & Fruits & 1.1 \\
\hline Guava & Psidium guajava & Myrtaceae & fruits/seeds & 1.1 \\
\hline \multirow[t]{2}{*}{ Moriga } & Moringa Oleifera & Moringacea & $\begin{array}{l}\text { Leaves/flower } \\
\text { s }\end{array}$ & 4.7 \\
\hline & Nuclea Dedirrichi & Rubiaceae & fruits/seeds & 1.8 \\
\hline Wild Mango Tree or Dilka & irvingia gabolensis & Irvingiaceae & Fruits & 1.6 \\
\hline Cola & Cola Giganta & Sterculiaceae & Fruits & 1.3 \\
\hline \multirow[t]{2}{*}{ Star Apple } & Chrysoplyllum albidum & Sapotaceae & Fruits & 1.2 \\
\hline & Blighia sapida & Sapindaceae & fruits & 1 \\
\hline Wild vegetable & myranthus arboreus & Moraceae & Fruits & 1.2 \\
\hline Medicinal plant & Alhornea cordifolia & Euphorbiaceae & Fruits & 1.8 \\
\hline \multirow[t]{2}{*}{ Fig Tree } & Ficus thonigi & Moraceae & Fruits & 2.1 \\
\hline & Musanga cecropiodes & Moraceae & Flower & 2.8 \\
\hline Solalum spp & $\underline{\text { Solanum pimpinellifolium }}$ & Solanaccea & $\underline{\text { seeds }}$ & 1.5 \\
\hline Maize & Zea mays & $\underline{\text { Poaceae }}$ & Seeds & 2.3 \\
\hline Pepper & Capsicum annuum & Piperaceae & Seeds & 2.1 \\
\hline four o'clock family & Boerhavia diffusa & Nyctaginaceae & $\underline{\text { Flowers }}$ & 2.2 \\
\hline \multirow[t]{2}{*}{ Guinea Grass } & Panicum maximum & Gramineae & Seeds & 2.7 \\
\hline & & & & 66.3 \\
\hline
\end{tabular}


Table 2: Plant Species Consumed by Common Bulbul in the Study Area

\begin{tabular}{|c|c|c|c|c|}
\hline Common Name & Scientific Name & Family & $\begin{array}{l}\text { Parts } \\
\text { Eaten }\end{array}$ & $\begin{array}{l}\text { Observation } \\
(\%)\end{array}$ \\
\hline \multirow[t]{7}{*}{ Butter fly } & Graphium pylades & Papilionidae & $\begin{array}{l}\text { Adult } \\
\text { winged }\end{array}$ & 4.2 \\
\hline & Papillio cynorta & Papilionidae & $\begin{array}{l}\text { Adult } \\
\text { winged }\end{array}$ & 3.1 \\
\hline & Amouris tartarreu & Danaidae & $\begin{array}{l}\text { Adult } \\
\text { winged }\end{array}$ & 2.4 \\
\hline & Leptocsia marginea & Pieridae & $\begin{array}{l}\text { Adult } \\
\text { winged }\end{array}$ & 1.8 \\
\hline & Eritis melania & Hesperidae & $\begin{array}{l}\text { Adult } \\
\text { Winged }\end{array}$ & 1.8 \\
\hline & Anthene lachares & Hesperidae & $\begin{array}{l}\text { Adult } \\
\text { Winged }\end{array}$ & 0.5 \\
\hline & Colotis evippe & pieridae & $\begin{array}{l}\text { Adult } \\
\text { winged }\end{array}$ & 0.53 \\
\hline \multirow[t]{2}{*}{ Termites } & Macrotermes bellicosus & Termitidae & $\begin{array}{l}\text { Adult } \\
\text { winged }\end{array}$ & 1.3 \\
\hline & Macrotermes natalensis & Termitidae & $\begin{array}{l}\text { Adult } \\
\text { winged }\end{array}$ & 0.92 \\
\hline Green Bug & Nezera viridula & Pentatomidae & $\begin{array}{l}\text { Adult } \\
\text { winged }\end{array}$ & 2.5 \\
\hline \multirow[t]{3}{*}{ Caterpillars } & Anapha venata & Notodontidae & Whole & 0.77 \\
\hline & Anaphe reticulata & Notodontidae & Larva & 1.4 \\
\hline & Anaphe infracta & Notodontidae & Larva & 1.6 \\
\hline \multirow[t]{3}{*}{ Moths } & Platysphinx phyllis & Sphingidae & Ault winged & 1,3 \\
\hline & Ebodina lagoana & $\underline{\text { Tortricidae }}$ & $\begin{array}{l}\text { Adult } \\
\text { winged }\end{array}$ & 1.2 \\
\hline & Phragmataecia fuscifusa & $\underline{\text { Cossidae }}$ & $\begin{array}{l}\text { Adult } \\
\text { winged }\end{array}$ & 2.6 \\
\hline \multirow[t]{5}{*}{ Grasshoppers } & Acridium perigrinum & Acrididae & $\begin{array}{l}\text { Adult } \\
\text { winged }\end{array}$ & 1.4 \\
\hline & $\begin{array}{l}\text { Cyrtacanthacris aeruginosa } \\
\text { unicolor }\end{array}$ & Acrididae & $\begin{array}{l}\text { Adult } \\
\text { winged }\end{array}$ & 1.6 \\
\hline & Schistocerca gregaria & Acrididae & $\begin{array}{l}\text { Adult } \\
\text { winged }\end{array}$ & 1.7 \\
\hline & & & $\begin{array}{l}\text { Adult } \\
\text { winged }\end{array}$ & 0.98 \\
\hline & Zonocerus variegatus & Pyrgomorphidae & Whole & 0.41 \\
\hline \multirow[t]{2}{*}{ Beetles } & Oryctes boas & Scarabaeid & Whole & 0.99 \\
\hline & & & & 33.7 \\
\hline
\end{tabular}




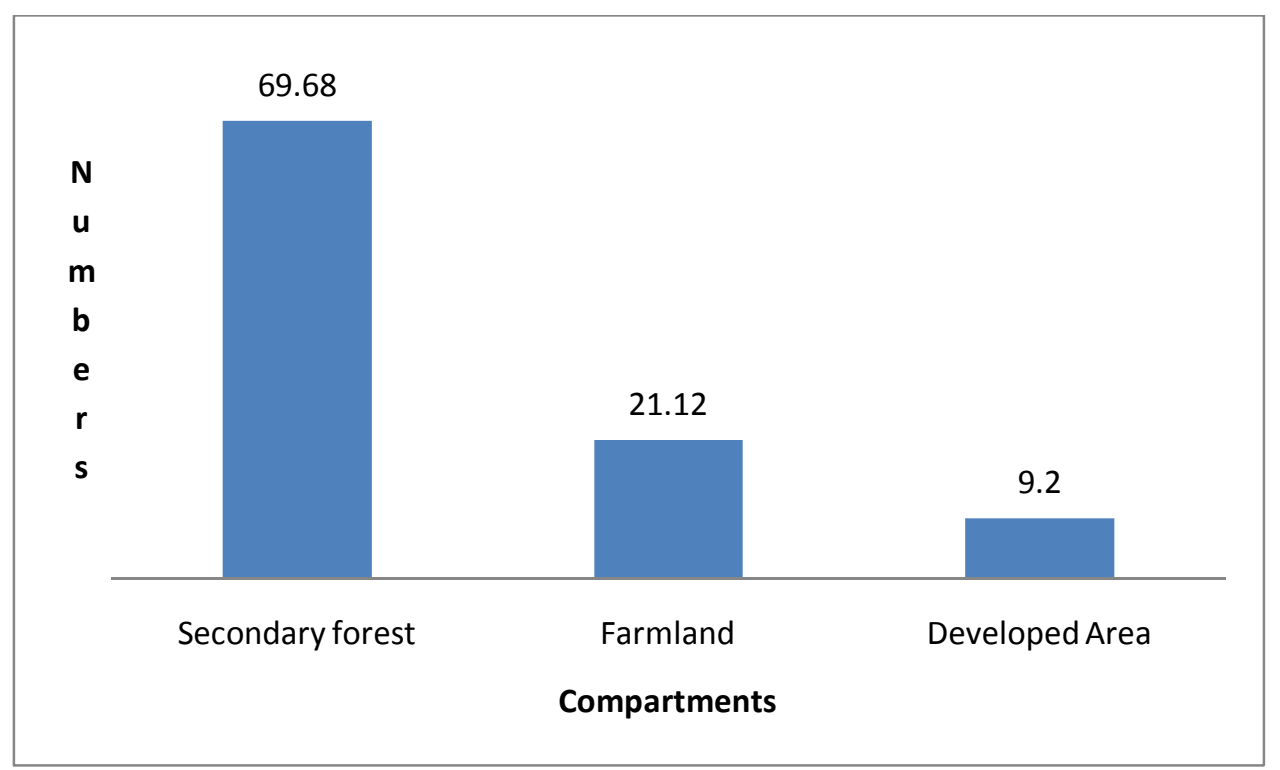

Figure 1: Utilized compartments in the Study Area

\section{DISCUSSIONS}

From the result obtained in this study it showed that the Common Bulbul consumed variety of plant species and insects. Ali (1970) reported that the Red-vented Bulbul Pycnonotus cafer nipped open mature buds of mistletoe (Loranthaceae) and probed into the exposed corolla tubes for nectar. In Africa, species such as Criniger barbatus and Andropadus tephrolaemus took all their fruits from a perch, while another species Andropadus latirostris frequently used its wings to pick a fruit while fluttering or flying (Moermond 1990). Gleaning of fruits while airborne has also been recorded in the Square-tailed Black Bulbul Hypsipetes ganeesa in southern India (Balakrishnan, 2007). The most consumed plants materials are the fig trees (Ficus Exaparata and Ficus Pilota). This is in agreement with (Rana, 1970) who reported Bulbuls constituted the major frugivores of Streblus asper fruits in the mixed dry deciduous forests in India. From this study the fruits nectar and flowers were higher (66.3\%) than the insects $(33.7 \%)$ consumed. This is consistent with (Narang, 1989) who reported that fruits comprised a major proportion of diet for bulbul species (Pycnonotus luteolus and Pycnonotus. cafer) in the tropical dry evergreen forest in India. Ali, and Ripley (1996) who carried out similar research observed that $74 \%$ of the feeding visits by birds on fruit bearing plants were made by two species of bulbuls, Pycnonotus. cafér and Pycnonotus. luteolus in a dry mixed deciduous forest in Western Ghats. In this present study, it was observed that the common bulbul consumed various species of insects, which is in agreement Hsu and Lin (1994) report that the Bulbuls consumed insects in the order Coleoptera was their main food sources in the oil palm plantation. The most preferable beetle was the pollinating weevil; Elaeidobius kamerunicus (Curculionidae) followed by rove beetle (Staphylinidae) and bark beetle (Scolytidae). Besides that, this bird also fed on leafhoppers (Order Homoptera: Cicadellidae), mosquitoes (Order Diptera: Culidae), bugs (Order Hemiptera) and ants (Order Hymenoptera: Formicidae). However, this bird species completely avoided feeding on insects from the order Odonata, Orthoptera, Dictyoptera and $s$ in the oil palm ecosystem. Carlson and Owre (2009) also reported that Bulbuls in Haiwai fed on seeds, fruits and nectar of plant species, variety of insects and small reptiles. The rich proteins in invertebrates promote faster growth, but they are more difficult to obtain than plant food (Morton, 1973, Earle, and Oatley. 1983).

In this study, it was observed that the Common Bulbul consumed variation of food-intake through the day: Feeding in Common Bulbul occurs intermittently throughout the day. The intensity of food-intake gets accelerated from the awakening after the reconnection calls and then gradually slows down. During dry season days, they start feeding in early hours (0600 to 0630 hours) but during wet season days, it starts as late as 0730 hours. The intensity of food intake again increases around 1430 hours in the dry season and 1530 hours in wet season. They spend on an average $62.2 \%$ of the day time for feeding in dry season (average day length-12 hours) and $56.12 \%$ in wet season (average day length-11 hours). Light rain showers are no obstacle for feeding to these birds but feeding activities are restricted during heavy rainfall. Many species of birds spend more than $50 \%$ of their day foraging and feeding, particularly in the morning and evening (Wienecke and Robertson, 2002; Scott et al., 2003) purposely to reduce risk of predation, maximize energy store and increase social activities. It was also observed that change in season play a major role in the diet of these birds. Feeding depend on the available fruits, or seeds which are 
suitable for consumption. These observations are in agreement with (Balakrishnan, 2010; Wilson et al, 2002). This is also consistent with Root and Hughes (2012) who reported that European raptors feed exclusively on animal food, apart from the few exceptional such as the honey Buzzard which like to eat soft fruits. Kirkwood (2009) noted that some bird species change their diet with season; species for which crops form a large percentage of their diet include Ducks, Geese and Doves etc. Farms provide three major sources of food for birds including; invertebrates of the soil, crops and naturally occurring plants and green vegetation of the growing plants ( $\mathrm{Li}$ and $\mathrm{Wu}$, 2005; Las-Casas et al., 2012). Avian species of various groups are excellently adapted for various means of obtaining food and many of them are food specialist (Wellicome et al., 2013).

From the field observations in this study, the Common Bulbul carried out its foraging activities in different ecosystem. It was observed utilize the three compartments in the study area Secondary forest, Farmland and Developed area. From the result obtained, $68.9 \%$ of the food consumed is obtained from the secondary forest, $21.12 \%$ from the farmland while, 9.2\% from the developed Area. This result is confirmed by Corlett (1998) who noted that Common Bulbul using different foraging microhabitat and in diet have been used by these birds to reduced competition, which makes co-existence possible for closely related species. Common Bulbul is selective in their diet. From field observation, it was noted that these bird species does not consumed all fruits and insects in the wild. This is consistent with Royama (1970) who reported that many bird species often feed selectively, and utilizes such factors as prey palatability, nutritive value, abundance and prey size and hardness. It appears that, though birds were living in suburban areas, they were still more dependent on wild plant species for food as compared to other frugivorous birds, thus causing minimal harm to human crops (Dhindsa and Saini, 1994). The consumption of leaves and flowers of Moringa Oleifera, Delonis regia and Boerhavia diffusa was an interesting observation because leaf consumption is common not in birds. This is consistent with Anthal and Sadi (2013) who reported the consumption of leaves by Jungle Babbler (Turdoides striatus sindianus).

\section{CONCLUSION}

The results of this study clearly indicate that Jungle Common Bulbul (Pycnonotus babatus) consumed both plant and animal resources available to them in the study area. But, compared to insect's foods, the plant food, mainly fruits and seeds are consumed in larger proportions. The Common Bulbul therefore help in the dispersal of seeds and keep check on various harmful insects like grasshoppers, beetles, termites, caterpillars etc., which are injurious to the agricultural crops and stored grains. The Common bulbul is a useful species for farmers.

\section{ACKNOWLEDGMENTS}

The authors are very grateful to the staff and management of Leventis Foundation Nigeria Ltd and Agricultural Training School for their support during the period of the study.

\section{REFERENCES}

Ali S. and Ripley S.D., Handbook of the Birds of India and Pakistan, Oxford University Press, London, 6, (1971)

Ali, S. (1970): Flower-birds and bird-flowers in India. J. Bombay Nat. Hist. Soc. 35(3): 573-605.

Anthal A. and Sahi D.N. Food and Feeding Ecology of Jungle Babbler, Turdoides striatus sindianus (Ticehurst) in District Jammu (J\&K), India International Research Journal of Environment Sciences ISSN 2319-1414 Vol. 2(7), 54-57,

Balakrishnan, P. (2007): Status, distribution and ecology of the Grey- headed Bulbul Pycnonotus priocephalus in the Western Ghats, India. Ph.D. thesis, Bharathiar University, Coimbatore

Balakrishnan P. 2010. Parental care strategies of grey-headed bulbul, Pycnonotus priocephalus in the Western Ghats, South India. Current Science, 98(5): 673-680.

Borrow, N. and Demey R. (2012). "A guide to the birds of western Africa". Princeton University Press

Chen, C. and F. Hsieh (2002): Composition and foraging behaviour of mixed-species flocks led by the Grey-cheeked Fulvetta in Fushan Experimental Forest, Taiwan. Ibis 144: 317-330.

Cody, M. L. (1974). Competition and the structure of bird communities. Princeton Univ. Press, Princeton, New Jersey.

Corlett, R. T. (1998). Frugivory and seed dispersal by birds in Hong Kong shrubland. Forktail 13: 23-27. 
del Hoyo, J., Elliott, A. \& Christie, D. (eds.) (2005). Handbook of the birds of the world. Volume 10. Cuckoo-shrikes to Thrushes. Barcelona: Lynx Edicions.

Dhindsa, M. S. and Saini, H. K. (1994) Agricultural ornithology: an Indian perspective. J. Biosci. 19: 391-402.

Earle, R.A. \& T.B. Oatley. 1983. Populations, ecology and breeding of the Orange Thrush at two sites in eastern South Africa. Ostrich 54: 205-212.

Hsu, M.J. \& Lin. Y.S. 1994. The annual cycle of the Chinese Bulbul Pycnonotus sinensis formosae in Taiwan. Acta Zool. Taiwanica 5: 33-39.

Hespenheide, H. A. (1971). Food preference and the extent of overlap in some insectivorous birds, with special reference to the Tyrannidae. Ibis 113:59-72.

Keay, R.W.J.,(1989), Trees of Nigeria. A review version of Nigerian trees $(1960,1964)$ by R. W. J Keay, C. F. A Onochie and D. P Strandfield. Claridon Press Oxford University press: Pp 476 pp.

Kitowski I. (2011). Breeding biology of the Grey-headed Bulbul Pycnonotus priocephalus (Aves: Pycnonotidae) in the Western Ghats, India. Journal of Threatened Taxa, 3(1): 1415-1424.

Kirkwood JK (1979). The partition of food energy for existence in the kestrel (Falco tinnunculus) and the barn owl (Tyto alba). Comparat. Biochem. Physiol. 63A:495-498.

Krebs B s, J.R. \& A. Kacelnik (1991): Decision making. Pp. 105-136. In: Krebs, J.R. \& N.B. Davies (Eds): Behavioural Ecology: An Evolutionary Approach. Blackwell Scientific, Oxford.

Las-Casas FM, Azevedo JSM, Dias FMM (2012). The community of hummingbirds (Aves: Trochilidae) and the assemblage of flowers in a Caatinga vegetation. Braz. J Biol. 72:51-58.

Lan SS, Zhang Q, Huang Q, Chen SH (2013). Breeding ecology of Chinese Bulbul in the urban environment of Hangzhou, China. Zoological Research, 34(3): 182-189. (in Chinese)

Li Y, Wu X (2005). Avian diversity in Wuhu City during summertime. Ying Yong Sheng Tai Xue Bao 16:1176-1179.

Liu XH. 1992. A preliminary study on the ecology of Red Whiskered Bulbul. Journal of Guangxi Academy of Science, 8(1): 54-62. (in Chinese

Mengistu and Salami (2007). Application of remote sensing and GIS inland use/land cover mapping and change detection in a part of south western Nigeria. African Journal of Environmental Science and Technology Vol. 1 (5), pp. $099-109$.

Morton ES. 1973. On the evolutionary advantages and disadvantages of fruit eating in tropical birds. The American Naturalist, 107(953): 8-22.

Morrison, M.L., C.J. Ral P h, J. Verner \& J.R. jehl jr. (Eds) (1990): Avian foraging: theory, methodology, and applications. Studies in Avian Biology No. 13. Cooper Ornithological Society, California.

Moermond, T.C. (1990): A functional approach to foraging: morphology, behaviour, and the capacity to exploit. Studies in Avian Biology 13: 427-430

Mozafarian V. (2005). Trees and Shrubs of Iran. Farhang-e-Moaser Publishing, Tehran 1003pp. [In Persian]

Narang M.L. and Lamba B.S., 1989 Food habits of jungle babbler, Turdoides striatus (Dumont) and its role in the ecosystem, Indian Journal of Ecology, 13, 38-45 (198

Rana B.D. (1970) .Some observations on food of the Jungle Babbler (Turdoides striatus) and the Common Babbler (Turdoides caudatus) in the Rajasthan desert, India, Pavo, Indian J. Ornithol., 8, 35-44.

Royama. T. 1970. Factors governing the hunting behaviour and selection of food by the great tit (Paris major L.). Journal of Animal Ecology 39(3): 619.668.

Root T, Hughes L (2005). Present and future phenological changes in wild plants and animals. In: Lovejoy T.E. and Hannah. L. (Eds.) Climate Change and Biodiversity, Yale University Press, New Haven \& London. p. 61.

Scott SN, Clegg SM, Blomberg SP, Kikkawa J, Owens IP (2003). Morphological shifts in island-dwelling birds: the roles of generalist foraging and niche expansion. Evolution 57:2147-2156.

Wienecke, B, Robertson G, (2002). Foraging areas of king penguins from Macquarie Island in relation to a marine protected area. Environ. Manage. 29:662-672.

Wilson S., Fatemi S.M.R. and Collegues (2002). Status of coral reefs of Persian /Arabian Gulf and Arabian Sea Region. Status of Coral Reefs of the Worlds.53-62.

Cite this Article: Okosodo E.F., Orimaye J.O. and Obasogie F.O. (2016). Food and Feeding Ecology of Common Bulbul (Pycnonotus barbatus) in Leventis Foundation Agricultural School llesa South Western Nigeria. Greener Journal of Agricultural Sciences, 6(1): 010-016, http://doi.org/10.15580/GJAS.2016.1.121615169. 